\title{
PELANGGARAN PRINSIP KESANTUNAN BERBAHASA DALAM FILM BUMI MANUSIA KARYA HANUNG BRAMANTYO DAN IMPLIKASINYA TERHADAP PEMBELAJARAN BAHASA INDONESIA DI SMA
}

\author{
Winda Gunansi*1, Khusnul Khotimah ${ }^{2}$, Wahyu Asriyani ${ }^{3}$ \\ Prodi Pendidikan Bahasa dan Sastra Indonesia, Fakultas Keguruan dan Ilmu Pendidikan, \\ Universitas Pancasakti Tegal, Indonesia \\ e-mail:*11windagunansi.sj@gmail.com, 2khusnul_khotimah@upstegal.ac.id, \\ 3asriyani1409@gmail.com
}

\begin{abstract}
ABSTRAK
Penelitian ini mengkaji pelanggaran prinsip kesantunan berbahasa dalam film Bumi Manusia karya Hanung Bramantyo dan implikasinya terhadap pembelajaran bahasa Indonesia di SMA. Tujuan penelitian ini untuk mendeskripsikan pelanggaran prinsip kesantunan berbahasa yang terdapat dalam dialog antar tokoh pada film Bumi Manusia karya Hanung Bramantyo serta mendeskripsikan implikasi hasil penelitian terhadap pembelajaran Bahasa Indonesia di SMA. Pendekatan yang digunakan dalam penelitian ini yaitu deskriptif kualitatif. Data diidentifikasi berdasarkan teori Leech. Teknik pengumpulan data menggunakan teknik simak dengan teknik lanjutan teknik catat. Berdasarkan penelitian, terdapat banyak tuturan yang melanggar prinsip kesantunan berbahasa, diantaranya melanggar maksim kebijaksanaan, maksim penerimaan, maksim kemurahan, maksim kerendahan hati, maksim kecocokan, dan maksim kesimpatian. Penelitian ini diimplikasikan terhadap pembelajaran bahasa Indonesia di SMA kelas XI kurikulum 2013 dalam kompetensi dasar 3.19 dan 4.19 pada materi drama.
\end{abstract}

Kata kunci: pelanggaran prinsip kesantunan berbahasa, Film Bumi Manusia, implikasi pembelajaran Bahasa Indonesia

\begin{abstract}
This study examines the violation of the principle of politeness in language in Bumi Manusia Movie by Hanung Bramantyo and the implications for learning Indonesian in high school. The purpose of this study is to describe the violation of the principle of politeness in the language contained in the dialogue between characters in Bumi Manusia Movie by Hanung Bramantyo and to describe the implications of the research results on Indonesian language learning in senior high schools. The approach used in this study is descriptive qualitative. The data were identified based on Leech's theory. The data collection technique used the listening technique with the advanced technique of note-taking technique. Based on the study, there are many utterances that violate the politeness principle, including that violate of tact maxim, generosity maxim, approbation maxim, modesty maxim, agreement maxim, and sympathy maxim. This study has implications for learning Indonesian in senior high schools class XI 2013 curriculum in basic competencies 3.19 and 4.19 on drama material.
\end{abstract}

Keywords: violation of the principles of language politeness, Bumi Manusia Movie, implication of learning Indonesian Language. 


\section{PENDAHULUAN}

Bahasa ialah sebuah alat komunikasi manusia kepada sesamanya untuk berinteraksi dalam kegiatan sehari-hari. Sedangkan manusia merupakan makhluk sosial yang berkomunikasi dengan sesamanya. Oleh karena itu, manusia dan bahasa merupakan dua hal yang tidak bisa dipisahkan.

Kajian ilmu kebahasaan sangat luas, salah satunya pragmatik. Pragmatik ialah cabang linguistik yang mempelajari bahasa untuk berkomunikasi dalam situasi tertentu [1]. Dalam kajian pragmatik, konteks memiliki peranan yang sangat penting. Menurut Leech, dalam sebuah artikel dijelaskan bahwa konteks diartikan sebagai pengetahuan latar belakang dari peserta pertuturan yang dapat membantu penutur untuk mengartikan makna tuturan [2]. Pada hakikatnya sebuah kajian pragmatik merujuk pada perwujudan keahlian penutur untuk memakai bahasa yang selaras dengan faktor penentu dan tindak tutur komunikatif serta mencermati prinsip penggunaan bahasa secara benar disertai dengan konteks tuturannya. Dapat dipahami bahwa agar memahami makna tuturan, maka perhatikan terlebih dulu konteks penggunaannya seperti aspek siapa penuturnya, kepada siapa lawan tuturnya, tujuannya apa, dan lainnya. Pendayagunaan konteks pada usia anak 7 tahun di Madrasah Diniyah Ta'limul Huda ditujukan pada tempat, waktu, peristiwa dan suasana serta konteks orang sekitar [3].

Tindak tutur tidak hanya mengacu pada aktivitas berbicara saja, tetapi juga mengacu pada semua situasi dalam proses komunikasi. Tindak tutur adalah perilaku tuturan oleh pengguna bahasa dalam kegiatan komunikasi [4]. Kalimat yang dituturkan manusia dalam bentuk bahasa lisan maupun bahasa tulis harus memenuhi syarat. Salah satu syaratnya adalah menggunakan bahasa yang santun sehingga mampu bertutur kata lembut dan isi dari tuturannya jelas akan menyejukan hati lawan tuturnya.

Kesantunan berbahasa memiliki peranan penting dalam membentuk karakter positif penuturnya, itu sebabnya kesantunan berbahasa sering dikaitkan dengan kesopanan berbahasa dan etika dalam berbahasa. Ketiganya tidak bisa dipisahkan dan harus tetap ada dalam komunikasi atau berinteraksi sesama manusia. Dalam buku yang berjudul Berbahasa Secara Santun, Grice menyatakan bahwa suatu tuturan dapat dikatakan santun apabila penutur meminimalkan ungkapan kata atau tuturan yang tidak santun kepada lawan tutur [5]. Artinya, seorang penutur harus teliti memilih kata atau tuturan agar lawan tutur tidak merasa kecewa atas apa yang telah di ucapkan penutur.

Dalam kesantunan berbahasa terdapat beberapa prinsip atau maksim yang harus dipatuhi dalam setiap pertuturan. Banyak ilmuwan yang menjabarkan tentang prinsip kesantunan berbahasa, salah satunya adalah Geoffrey Leech. Menurut Leech, prinsip kesantunan berbahasa dibagi menjadi enam, yaitu maksim kebijaksanaan, maksim penerimaan, maksim kemurahan, maksim kerendahan hati, maksim kecocokan, dan maksim kesimpatian [6]. Maksim kebijaksanaan atau kearifan mengisyaratkan bahwa setiap peserta tindak tutur agar meminimalkan kerugian dan memaksimalkan keuntungan lawan tutur. Maksim penerimaan atau kedermawanan menuntut peserta tindak tutur untuk melebihkan kerugian diri sendiri. Maksim kemurahan atau pujian menghendaki agar setiap peserta tindak tutur memaksimalkan rasa hormat pada lawan tutur dan meminimalkan rasa tidak hormat pada lawan tutur. Maksim kerendahan hati menekankan pada semua peserta tindak tutur untuk selalu mengurangi rasa hormat pada diri sendiri. Maksim kecocokan atau kesetujuan mengharuskan semua peserta tindak tutur agar memaksimalkan kesetujuan diantara mereka. Maksim kesimpatian menganjurkan untuk melebihkan rasa simpati kepada lawan tutur.

Realisasi kesantunan berbahasa tidak hanya dalam kehidupan sehari-hari, melainkan juga terdapat dalam sebuah film. Film yaitu hasil kreatif para sineas dengan memadukan berbagai unsur layaknya gagasan, sistem nilai, pandangan hidup, keindahan, norma, tingkah laku manusia, serta kecanggihan teknologi [7]. Film menjadi media yang berpengaruh jika dibandingkan dengan media lainnya. Itulah yang menjadikan film tidak hanya digunakan sebagai sarana hiburan saja, film juga digunakan sebagai sarana penyampaian pesan. Pesan tersebut dapat berupa pendidikan, 
informasi umum, ataupun lainnya. Pesan dalam film memakai lambang-lambang yang ada pada pikiran manusia dalam bentuk isi pesan, suara, pertuturan, dan lainnya.

Terkadang tuturan yang diujarkan oleh para tokoh melanggar prinsip kesantunan berbahasa. Seperti yang ada pada film Bumi Manusia karya Hanung Bramantyo banyak melanggar prinsip kesantunan berbahasa. Film yang diangkat dari novel terkenal pada tahun 1980 dengan judul yang sama karya Pramoedya Ananta Toer yang menceritakan tentang kisah cinta Minke dan Annelies Mellema di atas pergulatan tanah kolonial awal abad ke-20. Permasalahan mulai ada ketika kebahagiaan Minke dan Annelies Mellema akan dihancurkan oleh kebijakan hukum bangsa asing yang menempati tanah pribumi.

Film Bumi Manusia merupakan film biografi sejarah Indonesia yang rilis pada tahun 2019, disutradarai oleh Hanung Bramantyo dan ditulis oleh Salman Aristo dengan memakai banyak bahasa, seperti bahasa Indonesia, Jawa, Madura, Belanda, Perancis, dan Inggris. Film ini masuk dalam jajaran film box office di Indonesia. Tidak semua film dapat dikategorikan film box office, karena sebuah film dapat dikatakan film box office apabila ditonton oleh lebih dari satu juta orang penonton selama penayangannya di bioskop. Selain itu, film karya Hanung Bramantyo ini juga mendapatkan banyak penghargaan dan mempunyai makna serta nilai-nilai edukasi yang digunakan sebagai bahan pembelajaran Bahasa Indonesia di SMA.

Pendidikan adalah sebuah usaha pendidik yang dilakukan secara sadar dan terencana, bertujuan untuk memberikan arahan guna menjadikan potensi jasmani dan rohani peserta didik lebih berkembang, cepat mencapai kedewasaan, serta menuntun peserta didik untuk melaksanakan tugas hidupnya [8]. Pembelajaran bahasa Indonesia di SMA memilik tujuan untuk mencerdaskan peserta didik dengan semua komponen yang ada. Mata pelajaran Bahasa Indonesia dibagi menjadi beberapa aspek, yaitu menyimak, membaca, menulis, dan berbicara.

Peserta didik memperoleh pelajaran tentang semua hal yang mendukung kehidupannya untuk masa yang akan datang, termasuk di dalam pelajaran bahasa Indonesia. Diharapkan dengan pelajaran bahasa Indonesia di sekolah, maka kesantunan berbahasa dapat dimasukan menjadi pembelajaran yang disenangi dan digemari oleh banyak peserta didik. Selain itu, diharapkan kesantunan berbahasa dapat mengubah sifat dan perilaku peserta didik agar lebih baik dari sebelumnya.

Hal ini peneliti akan mengaitkan antara pelanggaran kesantunan berbahasa yang terjadi dalam film Bumi Manusia karya Hanung Bramantyo dengan salah satu materi dalam pembelajaran Bahasa Indonesia di SMA. Penelitian ini akan diimplikasikan pada pembelajaran Bahasa Indonesia materi drama kelas XI SMA. Materi mengenai isi dan kebahasaan sebuah drama terdapat dalam kompetensi dasar 3.19 dan 4.19. Kompetensi dasar 3.19 menganalisis isi dan kebahasaan drama yang dibaca atau ditonton serta kompetensi dasar 4.19 mendemonstrasikan sebuah naskah drama dengan memperhatikan isi dan kebahasaan.

Berdasarkan semua permasalahan yang telah diuraikan, peneliti memillih film Bumi Manusia karya Hanung Bramantyo untuk diteliti dari segi kesantunan berbahasanya, terutama yang berbahasa Indonesia dan berbahasa Jawa dalam aspek pelanggaran prinsip kesantunan berbahasa yang dikemukakan oleh Leech beserta dengan implikasinya terhadap pembelajaran Bahasa Indonesia di SMA. Maka, judul yang peneliti gunakan pada penelitian ini adalah Pelanggaran Prinsip Kesantunan Berbahasa dalam Film Bumi Manusia Karya Hanung Bramantyo dan Implikasinya terhadap Pembelajaran Bahasa Indonesia di SMA. Tujuan penelitian ini untuk mendeskripsikan pelanggaran prinsip kesantunan berbahasa yang terdapat dalam dialog antar tokoh pada film Bumi Manusia karya Hanung Bramantyo serta mendeskripsikan implikasi hasil penelitian terhadap pembelajaran Bahasa Indonesia di SMA.

\section{METODOLOGI PENELITIAN}

Penelitian ini menggunakan pendekatan deskriptif kualitatif. Metode penelitian deskriptif yaitu metode yang mempunyai tujuan untuk membuat deskripsi dengan membuat gambaran, lukisan terstruktur, faktual dan cermat mengenai data, sifat-sifat serta hubungan 
fenomena-fenomena yang akan diteliti [8]. Sedangkan, penelitian kualitatif adalah penelitian yang berfokus untuk memahami fenomena tentang apa yang dialami oleh subjek penelitian, misalnya perilaku, persepsi, motivasi, tindakan, dan lainnya [9]. Berdasarkan penjabaran mengenai pendekatan deskriptif kualitif tersebut, maka peneliti berupaya memahami serta mendeskripsikan dengan kata-kata perihal wujud pelanggaran kesantunan berbahasa dalam film Bumi Manusia karya Hanung Bramantyo.

Sumber data yang digunakan ialah film Indonesia yang berjudul Bumi Manusia. Wujud datanya berupa penggalan tuturan yang diucapkan para tokoh dalam film Bumi Manusia karya Hanung Bramantyo. Tetapi tidak semua tuturan dapat digunakan sebagai data, hanya tuturan yang dianggap mengandung pelanggaran prinsip kesantunan berbahasa.

Berlandaskan sumber data serta wujud data, maka data yang berwujud tuturan antar tokoh dalam film Bumi Manusia karya Hanung Bramantyo diidentifikasikan berdasarkan bentuk pelanggaran prinsip kesantunan berbahasa menurut teori Leech. Jenis kesantunan berbahasa yang dimukakan oleh Leech dibagi menjadi enam, diantaranya maksim kebijaksanaan, maksim penerimaan, maksim kemurahan, maksim kerendahan hati, maksim kecocokan, dan maksim kesimpatian. Jadi setelah data terkumpul, kemudian data dikelompokan berdasarkan bentuk pelanggaran dari keenam maksim tersebut.

Penelitian ini menggunakan metode simak, teknik lanjutannya teknik catat untuk mengumpulkan data. Metode simak yaitu metode yang dilakukan dengan menyimak penggunaan bahasa [10]. Teknik catat adalah teknik mencatat beberapa bentuk yang berkaitan antara penelitian dengan penggunaan bahasa secara tertulis [11]. Jadi dalam hal ini peneliti hanya menyimak tuturan yang ada dalam film Bumi Manusia karya Hanung Bramantyo. Selanjutnya, peneliti mencatat semua hasil temuannya, lalu menyimpulkan hasil analisis didasarkan pada analisis data keseluruhan.

\section{HASIL DAN PEMBAHASAN}

\section{Hasil Penelitian}

\section{Pelanggaran Prinsip Kesantunan Berbahasa dalam Film Bumi Manusia Karya Hanung Bramantyo}

Hasil penelitian menunjukan bahwa film Bumi Manusia karya Hanung Bramantyo banyak melanggar prinsip kesantunan berbahasa. Ditemukan ada 85 tuturan yang melanggar prinsip kesantunan berbahasa dalam film Bumi Manusia karya Hanung Bramantyo. Terdapat 9,41\% tuturan yang melanggar maksim kebijaksanaan. 11,76\% tuturan yang melanggar maksim penerimaan. 30,59\% tuturan yang melanggar maksim kemurahan. 7,06\% tuturan yang melanggar maksim kerendahan hati. 34,12\% tuturan yang melanggar maksim kecocokan. Serta 7,06\% tuturan yang melanggar maksim kesimpatian. Adapun pembahasan dari hasil penelitian antara lain.

\section{Pelanggaran Maksim Kebijaksanaan (Tact Maxim)}

Pada prinsipnya maksim kebijaksanaan atau kearifan mengisyaratkan bahwa setiap peserta tindak tutur mengurangi kerugian lawan tutur atau melebihkan keuntungan lawan tuturnya. Pelanggaran maksim kebijaksanaan terjadi apabila penutur melebihkan kerugian lawan tutur dan mengurangi keuntungan lawan tutur. Maksim kebijaksanaan berpusat pada untung atau ruginya lawan tutur.

Konteks : Latar terjadinya peristiwa tutur ini ada di ruang Kantor Pengadilan Eropa. Tuturan tersebut dituturkan oleh Hakim kepada Minke dan Nyai Ontosoroh. Pada saat itu Hakim mengatakan bahwa Nyai Ontosoroh tidak berhak atas kekayaan Herman Mellema serta tidak memiliki hak asuh Annelies Mellema dan Robert Mellema. Selain itu Hakim juga membantah pernyataan Minke bahwa Minke dan Annelies Mellema sudah menikah. 


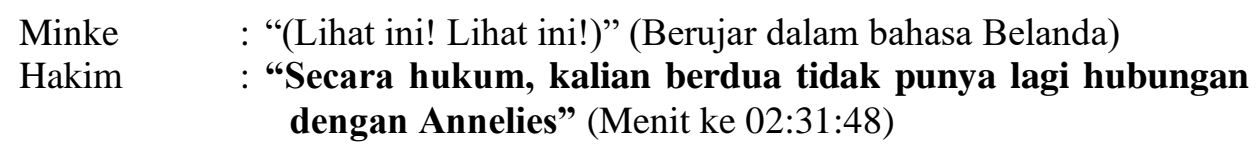

Percakapan di atas menunjukkan tuturan Hakim melanggar maksim kebijaksanaan. Bentuk pelanggaran tersebut terdapat pada tuturan "Secara hukum, kalian tidak punya lagi hubungan dengan Annelies". Tuturan tersebut dianggap melanggar maksim kebijaksanaan karena Hakim telah memaksimalkan kerugian terhadap lawan tuturnya, yaitu Minke dan Nyai Ontosoroh. Kerugian yang di dapat Minke dan Nyai Ontosoroh berupa keputusan sepihak dari Hakim yang tidak menganggap Minke sebagai suami Annelies Mellema serta Nyai Ontosoroh sebagai orang tua Annelies Mellema.

\section{Pelanggaran Maksim Penerimaan (Generosity Maxim)}

Pada dasarnya maksim penerimaan atau kedermawanan menuntut semua peserta tindak tutur meminimalkan keuntungan diri sendiri. Pelanggaran maksim penerimaan terjadi bila penutur memaksimalkan keuntungan diri sendiri. Maksim penerimaan berpusat kepada untung atau ruginya diri sendiri.

Konteks : Latar terjadinya peristiwa tutur ini ada di koridor depan kamar Minke. Tuturan tersebut dituturkan oleh Kangmas kepada Ibunda. Pada saat itu Kangmas ingin melaporkan isi buku catatan penting milik Minke kepada Romo atau Ayahnya.

\begin{tabular}{|c|c|}
\hline Ibunda & $\begin{array}{l}\text { : “Ono opo iki?" } \\
\text { "(Ada apa ini?)" }\end{array}$ \\
\hline Kangmas & $\begin{array}{l}\text { :Niki loh Bu, sedoyo alanipun Tirto wonten ing buku niki. } \\
\text { Kulo badhe matur Romo." (Menit ke 01:00:55) }\end{array}$ \\
\hline & $\begin{array}{l}\text { "(Ini Bu, semua kejelekan Tirto ada di buku ini. Saya akan lapor } \\
\text { ke Romo.)" }\end{array}$ \\
\hline Ibunda & $\begin{array}{l}\text { : "Koe durung dadi bupati, wis sinau ngedol adimu nek arep golet } \\
\text { alem? Kene bukune!" }\end{array}$ \\
\hline & $\begin{array}{l}\text { "(Kamu belum jadi bupati, sudah belajar menjual adikmu hanya } \\
\text { untuk mendapat pujian? Kemarikan bukunya!)" }\end{array}$ \\
\hline
\end{tabular}

Dialog tersebut memperlihatkan tuturan yang dilontarkan oleh Kangmas dianggap melanggar maksim penerimaan. Bentuk pelanggaran tersebut terdapat pada tuturan berbahasa Jawa "Niki loh Bu, sedoyo alanipun Tirto wonten ing buku niki. Kulo badhe matur Romo" yang dalam bahasa Indonesia berarti "Ini $\mathrm{Bu}$, semua kejelekan Tirto ada di buku ini. Saya akan lapor ke Romo". Tuturan tersebut dianggap melanggar maksim penerimaan karena Kangmas menginginkan keuntungan untuk dirinya sendiri. Keuntungan tersebut berupa pujian yang akan diberikan Romo kepada dirinya. Namun sayangnya sebelum Kangmas mengadu pada Romo, Ibunda menggagalkan rencananya dan merebut buku catatan milik Minke.

\section{Pelanggaran Maksim Kemurahan (Approbation Maxim)}

Pada prinsipnya maksim kemurahan atau pujian menghendaki agar setiap peserta tindak tutur untuk senantiasa mengurangi rasa tidak hormat kepada lawan tutur. Pelanggaran maksim kemurahan terjadi apabila penutur tidak melebihkan rasa hormat dan senantiasa mengurangi rasa hormat kepada lawan tutur. Maksim kemurahan berpusat pada rasa hormat dan tidak hormat kepada lawan tutur.

Konteks : Latar terjadinya peristiwa tutur ini ada di kamar Minke dalam rumah Keluarga Mellema. Tuturan tersebut dituturkan oleh Robert Mellema kepada Minke. Pada saat itu Minke hendak masuk ke kamarnya tetapi ternyata di dalam kamar Minke sudah terdapat Robert Mellema yang sedang duduk di meja kerja milik Minke sambil mengendus-endus tas milik Minke. 
(Robert Mellema melempar tas milik Minke)

Robert : "Kamar ini sudah bau binatang." (Menit ke 00:52:37)

(Robert Mellema tersenyum sinis)

Robert : "Demen koe karo adiku?"

"(Kamu suka dengan adikku?)"

Pembicaraan di atas menunjukan tuturan Robert Mellema melanggar maksim kemurahan. Bentuk pelanggaran tersebut terdapat pada tuturan "Kamar ini sudah bau binatang". Tuturan tersebut dianggap melanggar maksim kemurahan karena Robert Mellema memaksimalkan sindiran terhadap lawan tuturnya, yaitu Minke. Robert Mellema menyindir Minke dengan mengatainya binatang, hal itu Robert Mellema lakukan karena Robert Mellema sangat membenci bangsa Pribumi.

\section{Pelanggaran Maksim Kerendahan Hati (Modesty Maxim)}

Pada dasarnya maksim kerendahan hati menekankan pada setiap peserta tindak tutur untuk selalu memaksimalkan meminimalkan rasa hormat pada diri sendiri. Pelanggaran maksim kerendahan hati terjadi jika penutur senantiasa mengurangi rasa tidak hormat pada diri sendiri. Maksim kerendahan hati berpusat pada rasa hormat.

Konteks : Latar terjadinya peristiwa tutur ini ada di depan pintu rumah Keluarga Mellema. Tuturan tersebut dituturkan oleh Nyai Ontosoroh kepada Prajurit Pengadilan Eropa. Pada saat itu Prajurit Pengadilan Eropa ingin mengantarkan Dokter resmi yang dikirim langsung dari Pengadilan Eropa untuk menyembuhkan Annelies Mellema, namun kedatangannya membuat kericuhan besar sehingga Nyai Ontosoroh tak suka akan hal itu.

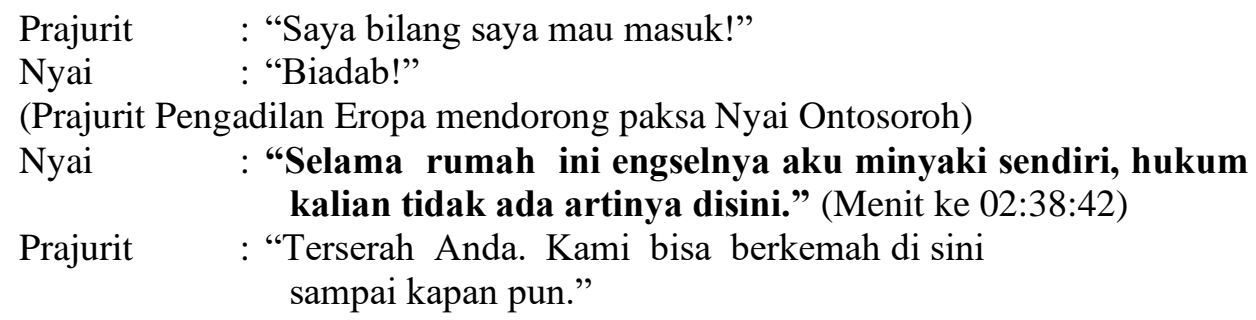

Percakapan tersebut memperlihatkan tuturan yang dilontarkan oleh Nyai Ontosoroh dianggap melanggar maksim kerendahan hati. Bentuk pelanggaran tersebut terdapat pada tuturan "Selama rumah ini engselnya aku minyaki sendiri, hukum kalian tidak ada artinya disini". Tuturan tersebut dianggap melanggar maksim kerendahan hati karena Nyai Ontosoroh memaksimalkan rasa hormat kepada diri sendiri dan meminimalkan rasa hormat pada lawan tutur. Dalam tuturan tersebut Nyai Ontosoroh sangat merendahkan hukum Eropa dan menjunjung tinggi kekuasaannya di rumahnya sendiri.

\section{Pelanggaran Maksim Kecocokan (Agreement Maxim)}

Pada prinsipnya maksim kecocokan atau kesetujuan mengharuskan semua penutur dan lawan tutur untuk melebihkan kesetujuan dan mengurangi ketidaksetujuan diantara mereka. Pelanggaran maksim kecocokan terjadi apabila peserta pertuturan saling tidak setuju terhadap tuturan yang dituturkan oleh lawan tutur. Maksim kecocokan ini berpusat pada kesetujuan maupun ketidaksetujuan antara penutur dan lawan tutur.

Konteks : Latar terjadinya peristiwa tutur ini ada di gazebo tepi danau milik keluarga Mellema. Tuturan tersebut dituturkan oleh Minke kepada Dokter Martinet. Pada saat itu ketika Dokter Martinet ingin menyentuh tangan Annelies Mellema, namun Annelies Mellema menolak tangan Dokter Martinet. Setelah itu Minke mencoba menyentuh tangan Annelies Mellema dan ternyata Annelies Mellema menerima sentuhan itu. 
Martinet : "Gadis yang saya rawat itu bukan cuma sakit fisik. Annelies
butuh kamu. Lebih dari dia membutuhkan ibunnya."

Minke : :Saya rasa tidak, Dok. Dokter pun tau bagaimana Annelies sangat mengagumi ibunya toh." (Menit ke 01:18:11)

Martinet : "Tapi tidak ada jaminan ibunya akan bersama dia selamanya. Apalagi, Annelies sangat ingin jadi Pribumi."

Dialog di atas menunjukan tuturan Minke melanggar maksim kecocokan. Bentuk pelanggaran tersebut terdapat pada tuturan "Saya rasa tidak, Dok. Dokter pun tau bagaimana Annelies sangat mengagumi ibunya toh". Tuturan tersebut dianggap melanggar maksim kecocokan karena Minke memaksimalkan ketidaksetujuan terhadap lawan tuturnya, yaitu Dokter Martinet. Minke tidak setuju pendapat Dokter Martinet yang mengatakan bahwa Annelies Mellema lebih membutuhkan Minke daripada ibunya.

\section{Pelanggaran Maksim Kesimpatian (Sympathy Maxim)}

Pada dasarnya maksim kesimpatian menganjurkan semua peserta tindak tutur untuk memaksimalkan rasa simpati dan meminimalkan rasa antipati kepada lawan tuturnya. Pelanggaran maksim kesimpatian terjadi bila penutur memiliki rasa tidak bersimpati pada lawan tuturnya. Maksim kesimpatian ini berpusat pada rasa simpati seorang penutur.

Konteks : Latar terjadinya peristiwa tutur ini ada di teras rumah Keluarga Mellema. Tuturan tersebut dituturkan oleh Nyai Ontosoroh kepada Annelies Mellema. Pada saat itu Annelies Mellema sedang duduk termenung memikirkan sesuatu, lalu tiba-tiba Nyai Ontosoroh mendekatinya.

\begin{tabular}{|c|c|}
\hline $\begin{array}{l}\text { Nyai } \\
\text { (Annelies }\end{array}$ & $\begin{array}{l}\text { : "Kenapa sih, Ann? Minke?" } \\
\text { m tak menjawab) }\end{array}$ \\
\hline $\begin{array}{l}\text { Nyai } \\
\text { (Annelies }\end{array}$ & $\begin{array}{l}\text { : "Sebegitunya kamu mengkhawatirkan dia?" } \\
\text { ya diam) }\end{array}$ \\
\hline Nyai & :"Sayang kamu sama dia?" \\
\hline Annelies & : "Minke tidak sayang aku ya, Ma?" \\
\hline Nyai & $\begin{array}{l}\text { : "Wis nggak usah dipikir, Ann.” (Menit ke 01:04:42) } \\
\text { "(Sudah tidak usah dipikirkan, Ann.)" }\end{array}$ \\
\hline
\end{tabular}

Pembicaraan tersebut memperlihatkan tuturan yang dilontarkan oleh Nyai Ontosoroh dianggap melanggar maksim kesimpatian. Bentuk pelanggaran tersebut terdapat pada tuturan "Wis nggak usah dipikir, Ann" yang dalam bahasa Indonesia berarti "Sudah tidak usah dipikirkan, Ann". Tuturan tersebut dianggap melanggar maksim kesimpatian karena Nyai Ontosoroh meminimalkan rasa simpati kepada lawan tuturnya, yaitu Annelies Mellema. Tuturan yang diucapkan Nyai Ontosoroh memang baik jika didengar oleh orang yang tidak terlibat langsung dalam pertuturan itu, namun jika didengar dari sudut pandang Annelies Mellema tuturan itu terkesan meremehkan dan tidak peduli terhadap perasaan Annelies Mellema.

\section{Implikasi Hasil Penelitian Pelanggaran Prinsip Kesantunan Berbahasa terhadap Pembelajaran Bahasa Indonesia di SMA}

Pembelajaran bahasa Indonesia memiliki beberapa keterampilan, antara lain menyimak, berbicara, membaca, dan menulis. Keterampilan tersebut berfokus pada peggunaan bahasa secara lisan maupun tertulis. Pembelajaran bahasa Indonesia mempunyai tujuan untuk meningkatkan kualitas bahasa yang digunakan peserta didik dalam berbagai situasi komunikasi. Situasi komunikasi inilah yang membentuk suatu tuturan itu dapat dikatakan santun atau tidak santun.

Pelanggaran kesantunan berbahasa bisa diimplikasikan dalam pembelajaran bahasa Indonesia kelas XI kurikulum 2013 materi drama pada KD 3.19 Menganalisis isi dan kebahasaan drama yang dibaca atau ditonton serta KD 4.19 Mendemonstrasikan sebuah naskah drama dengan memperhatikan isi dan kebahasaan. Tujuan pembelajaran dalam materi tersebut adalah peserta 
didik mampu menganalisis isi dan kebahasaan drama yang dibaca atau ditonton serta mendemonstrasikan sebuah naskah drama dengan memperhatikan isi dan kebahasaannya. Dengan menyisipkan pengetahuan mengenai pelanggaran kesantunan berbahasa, diharapkan peserta didik dapat lebih bijak dalam memilih kosa kata dalam bermain peran. Adapun langkah-langkah pembelajarannya meliputi sebagai berikut.

1. Kegiatan Pendahuluan

a) Pendidik melakukan salam pembuka lalu menanyakan kondisi kesehatan peserta didik.

b) Pendidik dan peserta didik melakukan doa secara bersama-sama sebelum melakukan pembelajaran.

c) Pendidik melakukan presesensi kehadiran peserta didik.

d) Pendidik memaparkan tujuan pembelajaran yang ingin dicapai pada KD 3.19 dan 4.19.

e) Peserta didik mendapatkan informasi mengenai hubungan pembelajaran sebelumnya dengan pembelajaran yang akan dilaksanakan.

f) Peserta didik menerima informasi mengenai hal-hal yang akan dipelajari khususnya pembelajaran teks drama.

2. Kegiatan Inti

(Pertemuan Pertama)

a) Peserta didik diberi rangsangan berupa penggalan film Bumi Manusia karya Hanung Bramantyo untuk memusatkan perhatian.

b) Peserta didik membaca buku siswa pada halaman 260-265.

c) Peserta didik mencatat informasi-informasi penting.

d) Peserta didik mengidentifikasi pertanyaan-pertanyaan yang ada dalam buku siswa halaman 265.

e) Peserta didik membentuk kelompok yang terdiri dari 3-4 orang.

f) Peserta didik mencari informasi untuk menjawab pertanyaan.

g) Peserta didik menetapkan kebahasaan teks drama yang telah didiskusikan.

h) Peserta didik menulis jawaban sesuai dengan hasil diskusi kelompok.

i) Setiap anggota kelompok mengoreksi ulang jawaban hasil diskusi sebelum presentasi.

j) Peserta didik membuktikan ketepatan hasil kerja kelompok dengan melakukan kegiatan presentasi hasil kelompok dan tanya jawab antar kelompok.

k) Perserta didik lainnya menyimak, menanggapi, mengajukan pertanyaan atau memberi saran yang berkaitan dengan hasil diskusi kelompok yang dipresentasikan.

(Pertemuan Kedua)

a) Peserta didik membaca buku siswa pada halaman 266-280.

b) Peserta didik membaca naskah drama yang berjudul Drama Tengah Malam karya Yandianto.

c) Pendidik menunjuk salah satu peserta didik untuk membacakan naskah drama tersebut dengan memperhatikan pelafalan, intonasi, nada atau tekanan, mimik, dan gerak-gerik tubuh.

d) Peserta didik diberi kesempatan untuk bertanya yang sesuai dengan hal-hal penting dalam mendemonstrasikan atau menyajikan drama.

e) Peserta didik membentuk kelompok yang terdiri dari 2 orang.

f) Peserta didik diharapkan berkumpul dengan kelompok yang sudah dibentuk sebelumnya.

g) Pendidik menginstruksi setiap kelompok untuk menyiapkan kostum dan latar cerita yang diinginkan.

h) Pendidik mempersiapkan nomor undian untuk urutan setiap kelompok mendemonstrasikan drama di depan kelas.

i) Perwakilan kelompok maju untuk memperebutkan nomor urut penampilan.

j) Kelompok lain yang tidak tampil diharap menyaksikan penampilan drama kelompok penampil dengan tenang.

k) Kelompok yang tampil memosisikan dirinya di depan kelas berdasarkan perannya. 
1) Semua kelompok bergantian mendemonstrasikan drama di depan kelas dengan memperhatikan isi, kebahasaan, dan menerapkan teknik bermain drama.

m) Pendidik dan peserta didik mengevaluasi kegiatan mendemonstrasikan drama yang sudah dilakukan.

n) Perserta didik menyampaikan kesimpulan sesuai pengalaman mendemonstrasikan drama di depan kelas.

3. Kegiatan Penutup

a) Peserta didik menyimpulkan materi.

b) Peserta didik memberikan umpan balik hasil pembelajaran.

c) Pendidik menutup pelajaran dengan berdoa dan memberi salam.

\section{Pembahasan}

Penelitian membahas terkiat dengan Pelanggaran Prinsip Kesantunan Berbahasa dalam Film Bumi Manusia Karya Hanung Bramantyo, Pelanggaran Maksim Kebijaksanaan (Tact Maxim), Pelanggaran Maksim Penerimaan (Generosity Maxim), Pelanggaran Maksim Kemurahan (Approbation Maxim), Pelanggaran Maksim Kerendahan Hati (Modesty Maxim), Pelanggaran Maksim Kecocokan (Agreement Maxim), dan Pelanggaran Maksim Kesimpatian (Sympathy Maxim). Penelitian ini dapat dijadikan sebagai bahan ajar untuk pedidik dalam kegiatan pembelajaran. Hasil analisis tuturan antar tokoh dalam film Bumi Manusia karya Hanung Bramantyo kiranya dapat menambah wawasan dalam bentuk pelanggaran prinsip kesantunan berbahasa. Dengan melibatkan film dalam sebuah pelajaran, diharapkan dapat menjadi solusi untuk menghilangkan kebosanan peserta didik pada model pembelajaran yang monoton. Seringkali peserta didik akan lebih aktif jika pembelajaran yang mereka ikuti itu menarik dan tidak membosankan.

\section{SIMPULAN}

Berdasarkan hasil penelitian pelanggaran prinsip kesantunan berbahasa dalam film Bumi Manusia karya Hanung Bramantyo dan implikasinya terhadap pembelajaran bahasa Indonesia di SMA, dapat disimpulkan bahwa telah ditemukan tuturan yang melanggar prinsip kesantunan berbahasa dalam film Bumi Manusia karya Hanung Bramantyo. Terdapat tuturan yang melanggar maksim kebijaksanaan, maksim penerimaan, maksim kemurahan, maksim kerendahan hati, maksim kecocokan, dan maksim kesimpatian. Hasil penelitian diimplikasi pada peembelajaran bahasa Indonesia kelas XI kurikulum 2013 dalam kompetensi dasar 3.19 menganalisis isi dan kebahasaan drama yang dibaca atau ditonton serta 4.19 mendemonstrasikan sebuah naskah drama dengan memperhatikan isi dan kebahasaan. Tujuan pembelajaran tersebut adalah peserta didik mampu menganalisis isi dan kebahasaan drama yang dibaca atau ditonton serta mendemonstrasikan sebuah naskah drama dengan memperhatikan isi dan kebahasaannya.

\section{REFERENSI}

[1] Nadar, F.X. 2009. Pragmatik \& Penelitian Pragmatik. Yogyakarta: Graha Ilmu.

[2] Nisa, Fithratun. 2016. "Pelanggaran Prinsip Kesantunan dalam Wacana Tutur Basuki Tjahaja Purnama (Ahok)". Stilistika: Jurnal Bahasa, Sastra, dan Pengajarannya. Online. 1, (1), 19-30. https://jurnal.stkippbjm.ac.id/index.php/STI/article/view/321 . (20 November 2020).

[3] Sudaryat, Yayat. 2009. Makna dalam Wacana: Prinsip-Prinsip Semantik dan Pragmatik. Bandung: Yrama Widya.

[4] Pranowo. 2009. Berbahasa Secara Santun. Yogyakarta: Pustaka Pelajar.

[5] Chaer, Abdul. 2010. Kesantunan Berbahasa. Jakarta: Rineka Cipta.

[6] Trianton, Teguh. 2013. Film sebagai Media Belajar. Yogyakarta: Graha Ilmu. 
[7] Hidayat, Rahmat, dan Abdillah. 2019. Ilmu Pendidikan "Konsep, Teori, dan Aplikasinya". Medan: Lembaga Peduli Pengembangan Pendidikan Indonesia.

[8] Djajasudarma, Fatimah. 2006. Metode Linguistik: Ancangan Metode Penelitian dan Kajian. Bandung: Refika Aditama.

[9] Moleong, Lexy J. 2017. Metodologi Penelitian Kualitatif (Edisi Revisi). Bandung: Remaja Rosdakarya.

[10] Sudaryanto. 1993. Metode dan Aneka Teknis Analisis Bahasa (Pengantar Penelitian Wahana Kebudayaan Secara Linguistik). Yogyakarta: Duta Wacana University Press.

[11] Mahsun. 2005. Metode Penelitian Bahasa. Jakarta: Raja Grafindo Persada. 